IZA DP No. 7121

Unemployment Insurance and Entrepreneurship

Knut Røed

Jens Fredrik Skogstrøm

January 2013 


\title{
Unemployment Insurance and Entrepreneurship
}

\author{
Knut Røed \\ The Ragnar Frisch Centre for Economic Research \\ and IZA \\ Jens Fredrik Skogstrøm \\ The Ragnar Frisch Centre for Economic Research
}

\author{
Discussion Paper No. 7121 \\ January 2013
}

IZA
P.O. Box 7240
53072 Bonn
Germany

Phone: +49-228-3894-0

Fax: +49-228-3894-180

E-mail: iza@iza.org

\begin{abstract}
Any opinions expressed here are those of the author(s) and not those of IZA. Research published in this series may include views on policy, but the institute itself takes no institutional policy positions. The IZA research network is committed to the IZA Guiding Principles of Research Integrity.

The Institute for the Study of Labor (IZA) in Bonn is a local and virtual international research center and a place of communication between science, politics and business. IZA is an independent nonprofit organization supported by Deutsche Post Foundation. The center is associated with the University of Bonn and offers a stimulating research environment through its international network, workshops and conferences, data service, project support, research visits and doctoral program. IZA engages in (i) original and internationally competitive research in all fields of labor economics, (ii) development of policy concepts, and (iii) dissemination of research results and concepts to the interested public.
\end{abstract}

IZA Discussion Papers often represent preliminary work and are circulated to encourage discussion. Citation of such a paper should account for its provisional character. A revised version may be available directly from the author. 
IZA Discussion Paper No. 7121

January 2013

\section{ABSTRACT \\ Unemployment Insurance and Entrepreneurship*}

Based on administrative registers from Norway, we examine how unemployment insurance (UI) and active labor market programs (ALMP) affect the transition rates from unemployment to regular employment and entrepreneurship. We find that the entrepreneurship hazard is highly responsive with respect to $\mathrm{UI}$ incentives, and that the probability of starting up a new business increases sharply around the time of UI exhaustion. We also find that while participation in ALMP has a positive impact on the employment hazard, it has no effect on entrepreneurship. We speculate that this reflects the programs' one-sided focus on job search rather than job creation.

JEL Classification: L26, J65, M13

Keywords: entrepreneurship, self-employment, unemployment

Corresponding author:

Knut Røed

The Ragnar Frisch Centre for Economic Research

Gaustadalléen 21

0349 Oslo

Norway

E-mail: knut.roed@frisch.uio.no

* This paper is part of the project "Entrepreneurship and gender in Norway", financed by the Norwegian Research Council (grant no. 201336). 


\section{Introduction}

A number of empirical studies have established that unemployed individuals have a higher probability of starting up their own business than employed workers; see, e.g., Evans and Leighton (1989; 1990), Meager (1992), Blanchflower and Meyer (1994), Kuhn and Schuetze (2001), Von Greiff (2009), and Berglann et al. (2011). This suggests that the pool of unemployed job seekers potentially constitute an important source of entrepreneurship. Yet, despite the existence of a huge empirical literature on unemployment insurance (UI) and its effect on job search behavior (see, e.g., Card, Chetty, and Weber, 2007), there is little evidence on the relationship between unemployment insurance and the transition to entrepreneurship.

The present paper seeks to fill this void. We take advantage of administrative registers from Norway and examine the transitions from unemployment to both dependent employment and to entrepreneurship. Unemployment has already been shown to play a crucial role for entrepreneurship endeavors in Norway. Based on data for mass layoffs caused by large bankruptcies, Røed and Skogstrøm (2010) estimate that incidences of job loss raise the transition rate to entrepreneurship by a factor of more than five. Hence, facilitating smooth transitions from unemployment to entrepreneurship is not only important as a strategy to keep unemployment down, it is potentially also crucial for the economy's ability to generate new businesses and jobs. The data we use in the present analysis cover a time period with an important reform in the UI system, whereby the maximum UI period was cut from three to two years. This gives us the opportunity to examine the impacts of UI incentives on job seekers' attempts to start their own business. As pointed out by Gaure et al. (2012), there is in Norway a close interrelationship between the design of UI institutions and the use of active labor 
market programs (ALMP's). Activation is frequently used to test claimants' willingness to work, and income from ALMP participation may substitute for exhausted (or soon to become exhausted) UI benefits. An additional aim of the present paper is therefore to examine the causal effects of ALMP participation on the transition rate to entrepreneurship.

An important feature of our analysis is that we apply a much wider concept of entrepreneurship than the self-employment definition frequently used in empirical applications. A common way of starting a new business in Norway - as well as in many other countries - is to set up a small limited liability company and then become an employee in that company. From an economics perspective, this is clearly similar to selfemployment since it entails the dual role of employing both human and financial capital into a business activity. Hence, we include in our entrepreneurship definition employees who either directly or indirectly (through other companies) own a significant share of the company in which they work. Our definition corresponds to the one used in Berglann et al. (2011). It turns out that the inclusion of “active owner employees” in the entrepreneurship definition raises the overall number of unemploymententrepreneurship transitions by around $40 \%$ compared to a pure self-employment definition.

We are not aware of many previous studies that examine the impacts of UI parameters on the transition from unemployment to entrepreneurship. Carrasco (1999) shows that UI claimants in Spain have much lower transition rates to self-employment than unemployed job seekers without UI, but speculate that this may result from state dependence related to previous self-employment spells, since self-employment do not generate UI entitlements. In contrast to Carrasco (1999), we focus entirely on persons who were employed prior to their unemployment spell and thus are eligible for UI ben- 
efits. Hence, in our application the variation in UI entitlement comes exclusively from UI exhaustion and sanctions. The only study we have found that is directly comparable to our own is Portugal and Addison (2008), who use Portuguese data to examine the transitions from unemployment to six different labor market states, including selfemployment. They identify a tendency for self-employment transitions to be particularly sensitive towards economic incentives, with a conspicuous pattern of "timing" towards the end of UI entitlement periods. We are also not aware of previous studies examining the impact of ALMP participation in general on the transitions from unemployment to entrepreneurship. However, Baumgartner and Caliendo (2008) report large positive effects of two German start-up programs particularly targeted at fostering selfemployment. The authors conclude that ALMP programs aiming at moving the unemployed into self-employment may prove to be among the most effective, both in Germany and elsewhere.

Our data show that only around two percent of Norwegian UI claimants make a direct transition from unemployment to entrepreneurship. Around 65 percent make a transition to regular employment. The statistical analysis indicates that UI eligibility to some extent discourages risky entrepreneurship endeavors among unemployed job seekers. A key finding from our statistical analysis is that the loss of UI benefits - due to exhaustion or sanctions - sharply raises the hazard rate from registered unemployment to entrepreneurship. In relative terms, the spike associated with UI termination is larger for transitions to entrepreneurship than for transitions to regular employment. There is also an interesting difference in the cyclicality of the two transition rates; while the employment hazard correlates strongly and positively with real GDP fluctuations, the entrepreneurship hazard is virtually non-cyclical. This implies that entrepreneurship becomes a relatively more important exit rout from unemployment in bad 
times. Finally, we find that while completed activation (participation in ALMP) significantly raises the hazard rate to regular employment, it has no effect on the entrepreneurship hazard. We argue that this finding reflects the programs' strong focus on job search as opposed to job creation.

\section{Data and empirical approach}

It is common in the literature to equate entrepreneurship to self-employment; see, e.g., Parker (2004) for a recent overview. However, many individuals who start new businesses do so by establishing or taking over small limited liability companies, either alone or together with friends/colleagues. They then become employed in their own company - or, in some cases, in another company which is again owned by their own company. These individuals will typically be classified as employed in register-based analyses of entrepreneurship, even though they may have played a pivotal role in setting up their own workplace and are exposed to the risks associated with being a residual claimant to the firm's earnings. From an economics perspective, we will argue that the essential features of entrepreneurship are that a person engages both labor and capital into an economic activity and operates as a residual claimant to the resultant earnings, while the mode of ownership is of secondary importance. We therefore employ an entrepreneurship concept incorporating self-employed as well as employees who own their own workplace, either directly or indirectly through other companies. ${ }^{1}$

\footnotetext{
${ }^{1}$ Following Berglann et al. (2011), we define an employee as entrepreneur if he/she owns at least 30 percent of the firm (directly or indirectly) or owns at least 10 percent and is a board member or CEO. Note that our definition of entrepreneurship does not require that the firm is "new"; nor does it require that the entrepreneur is necessarily the founder of the firm. The central feature of our definition is the combined employment of capital and labor into a business activity. Whether this occurs through the establishment of a new firm or through takeover - and potentially revitalization - of an existing firm is of secondary importance.
} 
The starting point of our analysis is the flow of new unemployment insurance (UI) claimants in Norway from October 1999 through September 2007. The basic requirements for UI eligibility in Norway are that the person in question has been in paid employment just prior to the unemployment spell, that he/she has lost this job involuntarily, that labor earnings last calendar year (or the average of the last three calendar years) exceeded a certain minimum level (currently around 120,000 NOK (16,000 €)), and that the claimant search actively for a new job and is willing to accept any relevant job offer. If these requirements are satisfied, the replacement ratio is 62.4 percent of past earnings (up to an annual earnings ceiling around 480,000 NOK). Little more than half of the unemployed job seekers in Norway satisfy the UI eligibility requirements at entry into unemployment (Gaure et al., 2012). Until the end of 2002, the maximum duration of UI benefits was three years. In January 2003, maximum duration was cut to two years for new claimants. Claimants may lose their benefit entitlement prematurely if they violate the active-search-requirements or refuse to accept suitable employment or program offers. Sanctions normally last for 8 weeks; see Røed and Westlie (2012) for details.

In our analysis, we define a "new" claimant in a month $t$ as a person who registered as unemployed job seeker and claimed UI benefits by the end of this month, but did not register in any of the months $t-1, t-2, \ldots, t-6 .^{2}$ We then follow each of these spells - month by month - until it ends by a transition to employment or to entrepreneurship, or is right-censored for other reasons. To record a transition, we require at least three months of absence from the unemployment register. The nature of the transition - in terms of employment, entrepreneurship, or other (right-censored) exit - is

\footnotetext{
${ }^{2}$ We condition on at least six months without prior unemployment to ensure that all the job seekers included in our analysis have full UI entitlements at the start of their spells.
} 
identified on the basis of employment registers, tax registers (with information on individual labor and business earnings), and business owner registers (covering all limited liability companies). ${ }^{3}$ During the unemployment spell, the claimant may make a transition to an active labor market program (ALMP) and may also be subject to a UI benefit sanction. We model these events in the spirit of the Timing-of-Events-approach (Abbring and Van den Berg, 2003), and estimate their impacts on the two finaldestination hazards separately during their occurrence and afterwards. Among the ALMP's offered, there are some programs targeted at encouraging entrepreneurship. In particular, it is possible to apply for the continuation of UI benefits for up to six months planning/development of a business idea, and for up to 3 months upon implementation of the project, provided that the idea is considered (by appropriate local authorities) to have some merit.

Table 1 provides a descriptive overview of the data we use. In total, around 157,000 UI spells are included in the statistical analysis. A little more than two thirds end in a direct transition to regular employment. Only around two percent end in a transition to entrepreneurship. Hence, entrepreneurship does not appear to be a quantitatively important exit route from insured unemployment. It is also notable that transitions to entrepreneurship tend to occur later in the unemployment spells than transitions to employment. The right-censored spells involve transitions to education, to other social insurance programs (rehabilitation, disability, early retirement), to inactivity without income support, migration, or death. Still ongoing spells are also rightcensored at the end of our observation window in September 2007.

${ }^{3}$ To ascertain consistency, we also exploit information from administrative social insurance registers and education registers. 


\begin{tabular}{|c|c|c|}
\hline \multicolumn{3}{|c|}{ Table 1.Descriptive overview of the data } \\
\hline & Men & Women \\
\hline \# Spells & 88,472 & 68,652 \\
\hline Percent of spells ending in & & \\
\hline Employment & 64.6 & 66.0 \\
\hline Entrepreneurship & 3.0 & 1.1 \\
\hline Per cent of spells involving participation in ALMP & 16.5 & 16.2 \\
\hline Per cent of spells involving premature benefit loss (sanction) & 30.1 & 25.9 \\
\hline Mean duration (months) of UI for spells ending in & & \\
\hline Employment & 4.0 & 5.8 \\
\hline Entrepreneurship & 6.6 & 7.3 \\
\hline
\end{tabular}

We observe labor market status by the end of each calendar month only; hence we set up the statistical model in terms of grouped hazard rates. We write the integrated month-specific hazard rate associated with destination state $k$ for individual $i$ in month $t, \varphi_{k i t}$, as functions of observed (time-varying) variables $x_{k i t}$ and (timeinvariant) unobserved individual characteristics $v_{k i}$ :

$$
\varphi_{k i t}=\int_{t-1}^{t} \theta_{k i s} d s=\exp \left(x_{k i t}^{\prime} \beta_{k}+v_{k i}\right), \quad k=1,2,3,4
$$

where $\mathrm{k}=1$ is employment, $\mathrm{k}=2$ is entrepreneurship, $\mathrm{k}=3$ is participation in ALMP, and $\mathrm{k}=4$ is a UI sanction (premature temporary loss of UI benefits). ${ }^{4}$ Note that while transitions to employment and entrepreneurship terminate the unemployment spell, the events of ALMP and a UI sanction both imply that the spell continues. While participating in ALMP, UI claimants may receive a "wage” rather than UI benefits, implying that UI entitlements are not exhausted in these periods.

The vector of observed covariates $x_{k i t}$ contains a number of individual characteristics, the status of UI claims and ALMP participation, and calendar time controls. Individual characteristics are represented by 5 age dummy variables (<30, 30-39, 40-49,

\footnotetext{
${ }^{4}$ Premature loss of UI benefits may also result from claimants' failure to register. UI claimants are obliged to confirm regularly (every fortnight) that they are still unemployed and still actively searching for work. If they fail to do so, UI payments will be halted until the confirmation arrives.
} 
50-59, >59), 5 education level dummy variables (compulsory only, lower secondary, upper secondary, higher education, unknown), 7 gender and family situation variables (man, women, married, women and married, \# children 0-3, \# children 0-3 and women, \# children 4-17, \# children 4-17 and women), 3 immigrant dummy variables (native, immigrant, immigrant from outside OECD), and 19 geographical dummy variables (one for each county in Norway).

The impacts of UI duration are modeled non-parametrically (one dummy variable for each duration month) and separately before and after the reduction of the maximum UI duration from three to two years. The duration baseline hazard is embedded in the construction of $x_{k i t}$. Note that it is the consumption of UI entitlements that defines the duration baseline in our model. The "duration clock" is stopped in months where benefits are not paid out, due to exhausted entitlements, a temporary sanction, or the substitution of ALMP earnings for UI benefits. In total, we use 61 UI duration dummy variables. The first duration month is selected as a reference, which is assumed to be common for the two UI regimes. We then have 36 dummy variables representing UI duration in the pre-reform regime (with maximum UI duration of 36 months), and 24 dummy variables representing UI duration in the post-reform regime. The last variable in each of these dummy variable sets indicate that UI entitlements are exhausted, and hence that the job seeker no longer claims UI benefits. The effects of ALMP participation and sanctions are represented in the appropriate hazards in the form of 4 dummy variables indicating ongoing or completed ALMP/sanction, respectively.

The impacts of calendar time are modeled by means of a monthly GDP growth indicator in addition to 12 seasonal dummy variables. The GDP growth indicator is based on the quarterly national real growth rates reported by Statistics Norway (ex- 
cluding offshore industries), and we have used a HP filter (Hodrick and Prescott, 1997) to produce a smooth monthly series. The fluctuations in the GDP indicator during our observation window are illustrated in Figure 1, together with the monthly rate of registered unemployment. Unsurprisingly, the two series correlate negatively, but the correlation is far from perfect. In particular, it may be noted that the cyclical turning point (the trough) is identified to have occurred much earlier according to the GDP-measure than what can be read off from unemployment figures. This is in line with findings reported by Gaure and Røed (2007) that the rate of unemployment tends to reach its cyclical turning point relatively long after the underlying business cycle conditions have changed.

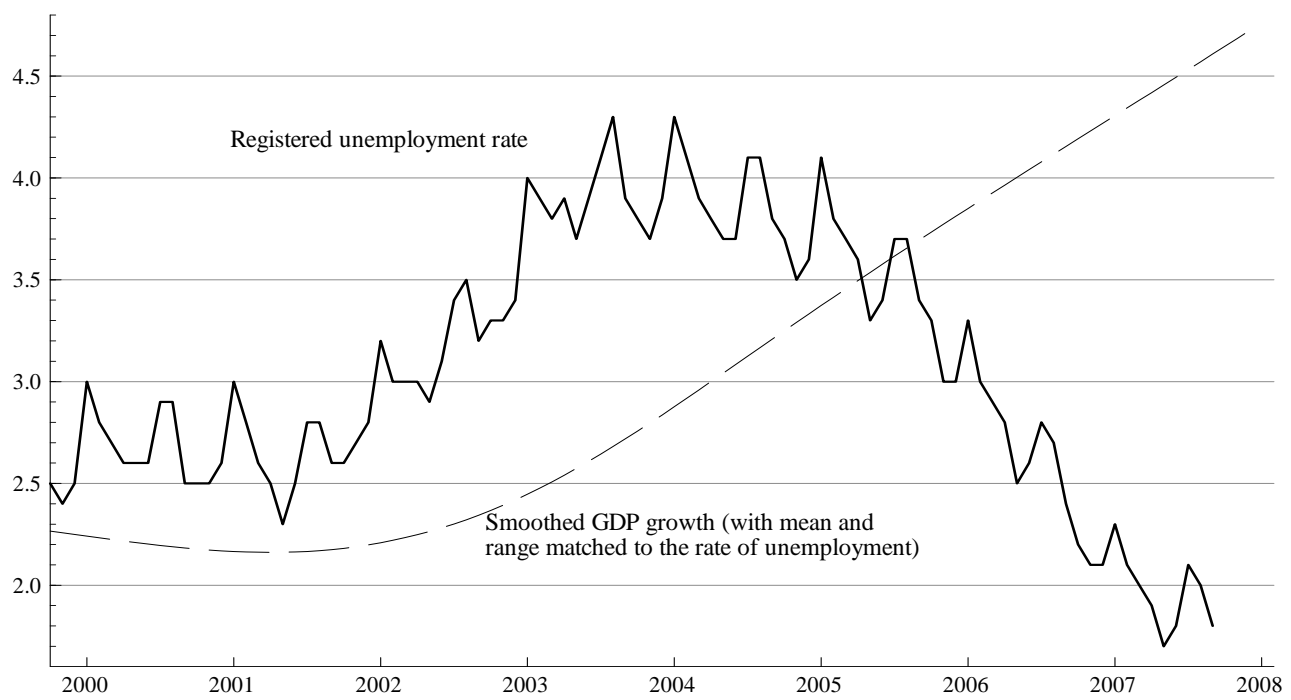

Figure 1. Registered unemployment rate and smoothed GDP growth 1999.10-2007.9 Sources: Registered unemployment rate: Statistics Norway. Labor market tightness indicator: Own calculations built on auxiliary model (Gaure and Røed, 2007).

To derive the likelihood function and estimate the model, we use the approach outlined in Røed and Westlie (2012). This approach is designed to account for the lefttruncation problem embedded in interval-censored data, and uses a completely nonpar- 
ametric strategy to represent the joint distribution of the four unobserved covariates. ${ }^{5}$ The latter implies that unobserved heterogeneity is approximated by a discrete distribution (Lindsay, 1983) with the number of mass-points chosen by adding points until it is no longer possible to increase the likelihood function (Heckman and Singer, 1984), and then determine the preferred number of location points on the basis of the Akaike Information Criterion (AIC). The scope for adding additional points is at all stages of the process evaluated by means of simulated annealing (Goffe, Ferrier, and Rogers, 1994) as well as by full estimation based on randomly selected starting-values for heterogeneity parameters. The optimization algorithm we use is thoroughly described and assessed in Gaure, Røed, and Zhang (2007).

\section{Identification}

The conditions for nonparametric identification of the multivariate mixed proportional hazard (MMPH) rate model used in the present paper are laid out in Abbring and Van den Berg (2003). In addition to the requirement of proportionality - in the sense that the proportional shift in a hazard rate caused by the manipulation of an observed covariate is the same regardless of the hazard's initial level - identification relies on a “no anticipation assumption”, requiring that claimants do not anticipate the realization of the stochastic process determining future events and adjust their ex ante behavior in response to that private information. With respect to the impacts of UI exhaustion, this assumption is obviously satisfied, since the timing of UI exhaustion is common

\footnotetext{
${ }^{5}$ The distribution of unobserved heterogeneity is assumed to be independent of observed characteristics at the time of entry into unemployment. We exploit Bayes' rule to derive the distribution of unobserved heterogeneity conditional on survival to the first "observation post" (the borders between the monthly intervals). For the sake of brevity, we do not present the (relatively complicated) likelihood function in this paper. A full description of the likelihood function for a similar model (and similar data) is given in Røed and Westlie (2012, Appendix).
} 
knowledge and fully captured by the systematic part of the model. With respect to the impacts of ALMP participation and UI sanctions, however, the no anticipation assumption is more questionable. It is probable that claimants are notified about upcoming events some time prior to their actual implementation, and that they respond to this private information by changing behavior. Since ALMP's as well as sanctions are typically implemented quickly once the relevant decision is made, we nevertheless view the potential violations of no-anticipation to be of minor importance in the present context.

Even though we apply a proportional hazard rate model, we emphasize that identification in our case does not rely solely on the proportionality assumption. An important additional source of identification comes from the abundance of exogenous time-varying covariates; see, e.g., McCall (1994), Brinch (2007) and Gaure et al. (2007). Of particular value for identification purposes in our case is the substantial cyclical and seasonal variation both labor demand and in the scale of labor market programs (see below). Time-varying variables give a sort of instrumental-variable type foundation for identifying the role of unobserved heterogeneity. The "exclusion restriction" is then that past values of these variables do not have a direct effect on the hazard rates, conditional on their present values, implying that they influence the contemporary hazards only through the already realized selection process; see also Eberwein et al. (1997, p. 663).

A particular feature of our analysis is that we model the impacts of UI duration separately before and after a reform that was implemented at a particular point in time (January 1, 2003). One may question how it is possible to identify separately the effects of the reform from the impacts of cyclical fluctuations. The answer to this question lies in the fact that the new and stricter regime was implemented for new spells 
only; hence for a long period of time the two regimes coexisted, in the sense that there were persons belonging to both regimes represented in the dataset at the same time. The focus of our analysis is in any case not to identify the effect of the reform as such, but to investigate how the reform affected the patterns of duration dependence.

\section{Estimation results}

The preferred model ended up having 18 support points in the distribution of unobserved heterogeneity. We first present the estimated UI duration effects on the four modeled events - before and after the reform. Figure 2 displays the regime-specific UI duration baselines with 95 percent confidence intervals, normalized such that firstmonth hazard rates are equal to the observed first-month event frequencies in the data. We may thus interpret the UI baselines in Figure 2 as the estimated hazard profiles for a representative entrant to UI. For example, focusing on the entrepreneurship hazard (panel B), we note that the representative agent's monthly transition probability increases from around 0.2 percent in the first month to around 1 percent the last few months before UI exhaustion, and further to 2-4 percent after exhaustion (marked by the vertical lines in the graphs). In a similar fashion, the transition rate to employment rises from around 8 percent in the beginning of the spell to 20-40 percent after UI exhaustion. The relative response to UI exhaustion is thus significantly larger for the entrepreneurship hazard than for the employment hazard. And while there is a general pattern of negative duration dependence in the employment hazard - particularly in the period prior to the cut in the maximum UI period - the entrepreneurship hazard remains almost constant until the rise during the last months of the entitlement period. This may reflect that while employability declines with unemployment duration (e.g., 
due to the use of statistical discrimination in the hiring process), the possibilities of starting up one’s own business remain more or less constant.
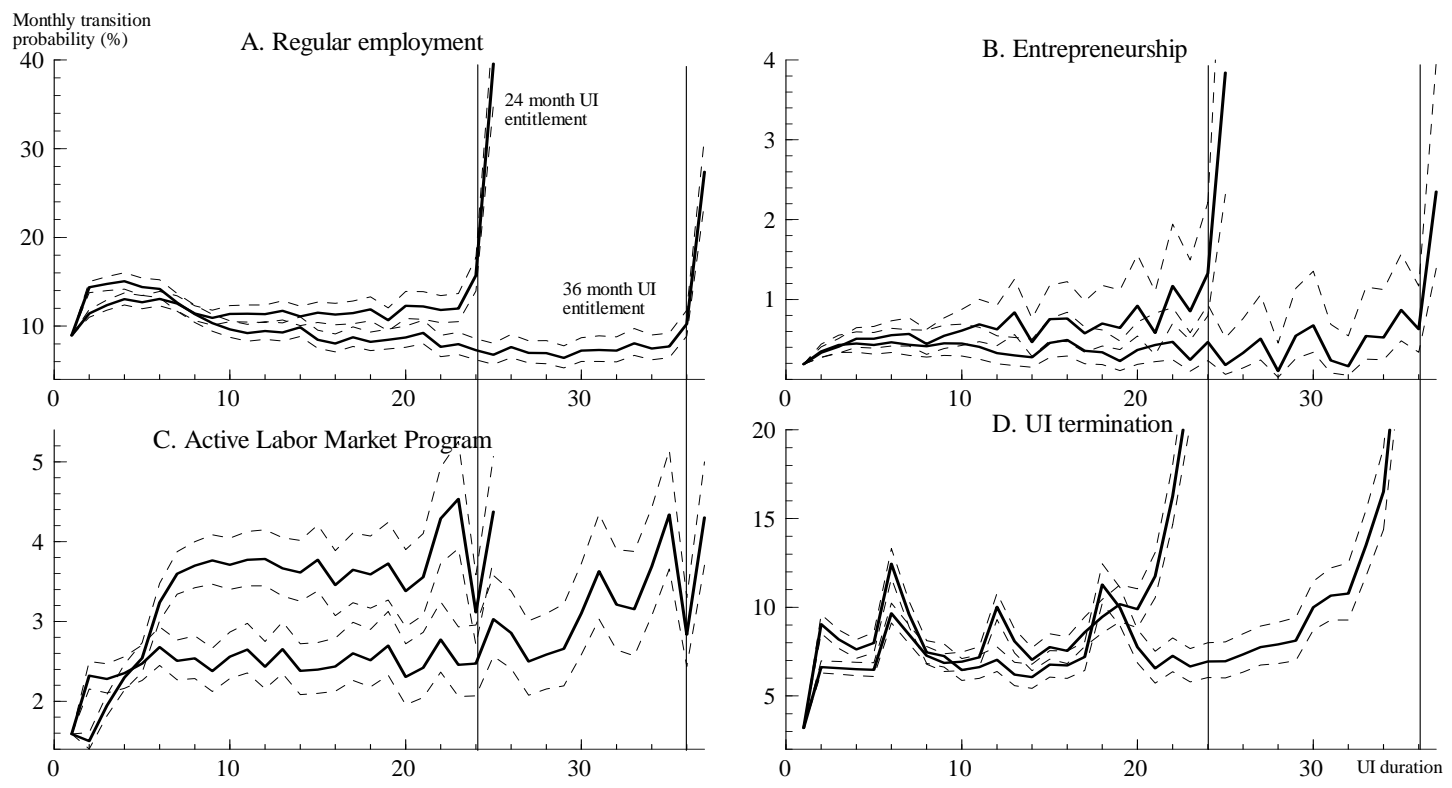

Figure 2. Estimated UI duration baseline hazard rates, with $95 \%$ confidence intervals. Note: All hazard rates are normalized to the observed average transition rate in the first duration month. Vertical lines indicate the timing of UI exhaustion before (36) and after (24) the 2003 reform.

In order to interpret the level of the transition rates illustrated in Figure 2 around the times of UI exhaustion, it is important to bear in mind that the graphs are normalized to a representative UI entrant, defined as one who has average transition rates in the first month of the spell. The group of unemployed actually experiencing UI exhaustion is strongly adversely selected - in terms of low employment and entrepreneurship propensities - hence they obviously have much lower transition rates than the representative entrant.

It is evident from Figure 2 that the spikes in the hazard rates around the times of UI exhaustion were shifted 12 months ahead in response to the 12 month reduction in maximum UI duration in 2003. This pattern should convincingly remove any doubts that it is indeed the loss of UI benefits that causes the hazard rates to rise around the time of exhaustion. 


\begin{tabular}{|c|c|c|c|c|}
\hline & Employment & Entrepreneurship & ALMP & $\underline{\text { Sanction }}$ \\
\hline \multicolumn{5}{|l|}{ ALMP } \\
\hline Ongoing & $\begin{array}{c}0.038 \\
(0.028)\end{array}$ & $\begin{array}{c}0.109 \\
(0.144)\end{array}$ & - & - \\
\hline Completed & $\begin{array}{c}0.067 * * * \\
(0.026)\end{array}$ & $\begin{array}{l}-0.028 \\
(0.116)\end{array}$ & $\begin{array}{c}0.215^{* * *} \\
(0.031)\end{array}$ & $\begin{array}{c}0.124 * * * \\
(0.018)\end{array}$ \\
\hline \multicolumn{5}{|l|}{ UI sanction } \\
\hline Ongoing & $\begin{array}{c}1.641^{* * *} \\
(0.026)\end{array}$ & $\begin{array}{c}2.492^{* * * *} \\
(0.180)\end{array}$ & $\begin{array}{c}-0.055^{* *} \\
(0.024)\end{array}$ & - \\
\hline Completed & $\begin{array}{c}0.787 * * * \\
(0.030)\end{array}$ & $\begin{array}{l}1.160 * * * \\
(0.194)\end{array}$ & $\begin{array}{c}-0.242 * * * \\
(0.024)\end{array}$ & - \\
\hline GDP growth (smoothed) & $\begin{array}{c}0.532 * * * \\
(0.024)\end{array}$ & $\begin{array}{c}0.101 \\
(0.113)\end{array}$ & $\begin{array}{c}0.304^{* * *} \\
(0.033)\end{array}$ & $\begin{array}{c}0.617^{* * * *} \\
(0.028)\end{array}$ \\
\hline \multicolumn{5}{|l|}{ Age } \\
\hline$<30$ & $\begin{array}{c}0.468 * * * \\
(0.016)\end{array}$ & $\begin{array}{c}-0.702 * * * \\
(0.079)\end{array}$ & $\begin{array}{c}0.082^{* * *} \\
(0.020)\end{array}$ & $\begin{array}{c}0.289 * * * \\
(0.017)\end{array}$ \\
\hline $30-39$ & $\begin{array}{c}0.199 * * * \\
(0.014)\end{array}$ & $\begin{array}{l}-0.030 \\
(0.055)\end{array}$ & $\begin{array}{l}0.015 \\
(0.018)\end{array}$ & $\begin{array}{c}0.035 * * \\
(0.015)\end{array}$ \\
\hline $40-49$ & Ref. & Ref. & Ref. & Ref. \\
\hline $50-59$ & $\begin{array}{c}-0.342 * * * \\
(0.019)\end{array}$ & $\begin{array}{c}-0.217^{* *} \\
(0.069)\end{array}$ & $\begin{array}{c}-0.086 * * * \\
(0.023)\end{array}$ & $\begin{array}{c}-0.074 * * * \\
(0.020)\end{array}$ \\
\hline$>59$ & $\begin{array}{c}-1.245^{* * *} \\
(0.033)\end{array}$ & $\begin{array}{c}-1.572 * * * \\
(0.141)\end{array}$ & $\begin{array}{c}-1.007 * * * \\
(0.040)\end{array}$ & $\begin{array}{c}-0.528 * * * \\
(0.031)\end{array}$ \\
\hline \multicolumn{5}{|l|}{ Education } \\
\hline Compulsory only & $\begin{array}{c}0.213 * * * \\
(0.023)\end{array}$ & $\begin{array}{c}0.253^{* * *} \\
(0.101)\end{array}$ & $\begin{array}{c}-0.288 * * * \\
(0.033)\end{array}$ & $\begin{array}{c}0.011 * * * \\
(0.026)\end{array}$ \\
\hline Lower secondary & Ref. & Ref. & Ref. & Ref. \\
\hline Higher secondary & $\begin{array}{c}0.371^{* * *} \\
(0.012)\end{array}$ & $\begin{array}{c}0.647 * * * \\
(0.053)\end{array}$ & $\begin{array}{c}-0.045^{* * *} \\
(0.014)\end{array}$ & $\begin{array}{c}-0.041^{* * *} \\
(0.012)\end{array}$ \\
\hline College/University & $\begin{array}{c}0.640 * * * \\
(0.019)\end{array}$ & $\begin{array}{c}0.923 * * * \\
(0.084)\end{array}$ & $\begin{array}{c}-0.241 * * * \\
(0.028)\end{array}$ & $\begin{array}{c}-0.048 * * \\
(0.022)\end{array}$ \\
\hline \multicolumn{5}{|l|}{ Gender and family situation } \\
\hline Women & $\begin{array}{c}-0.124 * * * \\
(0.013)\end{array}$ & $\begin{array}{c}-1.387 * * * \\
(0.088)\end{array}$ & $\begin{array}{c}-0.200 * * * \\
(0.017)\end{array}$ & $\begin{array}{c}0.051 * * * \\
(0.014)\end{array}$ \\
\hline Married & $\begin{array}{c}0.273^{* * *} \\
(0.016)\end{array}$ & $\begin{array}{c}0.759 * * * \\
(0.058)\end{array}$ & $\begin{array}{l}-0.005 \\
(0.021)\end{array}$ & $\begin{array}{c}-0.101^{* * *} \\
(0.018)\end{array}$ \\
\hline Women $\times$ married & $\begin{array}{c}-0.209 * * * \\
(0.020)\end{array}$ & $\begin{array}{c}-0.526 * * * \\
(0.103)\end{array}$ & $\begin{array}{c}-0.061 * * * \\
(0.026)\end{array}$ & $\begin{array}{c}0.099 * * * \\
(0.023)\end{array}$ \\
\hline \# Children 0-3 & $\begin{array}{c}-0.219 * * * \\
(0.014)\end{array}$ & $\begin{array}{l}-0.002 \\
(0.056)\end{array}$ & $\begin{array}{c}-0.083^{* *} \\
(0.018)\end{array}$ & $\begin{array}{c}-0.159 * * * \\
(0.016)\end{array}$ \\
\hline Women× \# Children 0-3 & $\begin{array}{c}-0.313 * * * \\
(0.021)\end{array}$ & $\begin{array}{c}-0.491 * * * \\
(0.126)\end{array}$ & $\begin{array}{c}-0.189 * * * \\
(0.029)\end{array}$ & $\begin{array}{c}-0.130 * * * \\
(0.023)\end{array}$ \\
\hline \# Children 4-17 & $\begin{array}{c}-0.020 * * * \\
(0.006)\end{array}$ & $\begin{array}{c}0.159 * * * \\
(0.023)\end{array}$ & $\begin{array}{c}0.028 * * * \\
(0.007)\end{array}$ & $\begin{array}{c}-0.002 \\
(0.006)\end{array}$ \\
\hline Women× \# Children 0-3 & $\begin{array}{l}-0.031 * \\
(0.017)\end{array}$ & $\begin{array}{c}-0.282 * * * \\
(0.110)\end{array}$ & $\begin{array}{c}0.023 \\
(0.022)\end{array}$ & $\begin{array}{c}0.051^{* * * *} \\
(0.018)\end{array}$ \\
\hline \multicolumn{5}{|l|}{ Country background } \\
\hline Immigrant & $\begin{array}{c}-0.120 * * * \\
(0.019)\end{array}$ & $\begin{array}{l}-0.060 \\
(0.076)\end{array}$ & $\begin{array}{c}0.057 * * \\
(0.024)\end{array}$ & $\begin{array}{c}0.063 * * * \\
(0.021)\end{array}$ \\
\hline $\begin{array}{l}\text { Immigrant from non- } \\
\text { OECD country }\end{array}$ & $\begin{array}{c}-0.518 * * * \\
(0.024)\end{array}$ & $\begin{array}{c}-1.333^{* * *} \\
(0.115)\end{array}$ & $\begin{array}{c}0.186^{* * *} \\
(0.029)\end{array}$ & $\begin{array}{c}0.026 \\
(0.025)\end{array}$ \\
\hline
\end{tabular}

Additional controls: Seasonal dummies (12),county dummies (19) and UI duration dummies (61). $*(* *)(* * *)$ Significant at the 10(5)(1) percent level. 
Table 2 presents some other estimation results of interest. Note that the proportional shifts in the hazard rates implied by the parameter estimates are equal to Exp(estimate). Since $\operatorname{Exp}(a)-1 \approx a$ for small $a$, small parameter estimates may be interpreted approximately as the relative change in the hazard rate resulting from a unit change in the corresponding explanatory variable.

The estimates reported in Table 2 confirm the importance of economic incentives for transitions to both regular employment and entrepreneurship. A UI sanction (temporary loss of UI benefits) is estimated to raise the employment hazard by $416 \%$ $((\operatorname{Exp}(1.641)-1) \times 100=416)$ and the entrepreneurship hazard by as much as $1109 \%$, ceteris paribus.

Participation in ALMP is estimated to have a weak positive effect (7 percent) on the transition rate to employment after the program is completed, but no effect whatsoever on entrepreneurship entry. We also find no lock-in effects of program participation. A probable reason for the failure of ALMP to foster entrepreneurship is that the programs focus more on job search than on job creation. In total we identify 30,186 cases of program participation in our data. Only in $4.3 \%$ of the cases were the programs specifically targeted at job creation. However, among the 652 program participants who later made a transition to entrepreneurship, as much as $46.8 \%$ of the cases involved programs that were targeted at job creation.

The hazard rate from unemployment to employment is strongly pro-cyclical. We have scaled the GDP growth index such that it has a unit range, implying that the change from the worst to the best cyclical conditions during our data window caused a rise in the employment hazard of $70 \%((\operatorname{Exp}(0.532)-1) \times 100=70)$, ceteris paribus. The cyclical improvement also coincided with higher transition rates to ALMP and 
higher sanction probabilities. ${ }^{6}$ By contrast, the transition rate to entrepreneurship displays a completely non-cyclical pattern.

The most notable estimate representing the influences of individual characteristics is the huge gender-divide in entrepreneurship propensity. Among unmarried without children, men's entrepreneurship hazard is three times as high as that of women. For married job seekers and for job seekers with small children, the gender gap in entrepreneurship entry is even larger. It is notable that the male-female entrepreneurship ratios identified in our analysis are very similar to those recorded for so-called "early stage entrepreneurial activity” in Norway in the Global Entrepreneurship Monitor (GEM); see Kelley et al. (2011). Another point to note is the different age profiles in transitions to employment and entrepreneurship; while the employment hazard declines monotonously with age, the entrepreneurship hazard rises until the forties, and then declines. The estimated entrepreneurship hazard is almost 75 percent lower for nonOECD immigrants than it is for both natives and for immigrants from OECD countries. In comparison, the corresponding differential in the employment hazard is "only" around 40 percent. These findings stand in some contrast to the popular view that immigrants turn to entrepreneurship as an alternative to paid employment, owing to hardto-document educational skills or discrimination in the labor market; see, e.g., Parker (2004, pp 129-132).

From a methodological perspective, it may be of some interest to take a look at the estimated unobserved heterogeneity distribution. As noted above, it contains 18 support points. 11 of these points are attributed a probability above $1 \%$. The single

\footnotetext{
${ }^{6}$ These coefficients may not have a purely causal interpretation, however. The reduction in the maximum duration of UI benefits from 3 to 2 years in 2003 was a part of a general drive towards a more thrifty and activation-oriented UI system. To some extent, this policy change was motivated by the improvement in job opportunities, but it was probably also a result of a change in policy priorities.
} 
most probable point is attributed a probability of $33 \%$. The estimated rank correlation matrix is presented in Table 3. It indicates that there is a positive correlation in unobserved employment and entrepreneurship propensities, and that these propensities also correlate positively with the unobserved program participation propensity, and negatively with the tendency to be exposed to a UI sanction.

Table 3.The joint distribution of unobserved heterogeneity. Estimated rank correlation matrix.

\begin{tabular}{lccc} 
& Entrepreneurship & ALMP & Sanction \\
Employment & 0.19 & 0.13 & -0.30 \\
Entrepreneurship & & 0.21 & -0.60 \\
ALMP & & & -0.32 \\
\hline
\end{tabular}

Note: The table is based on the preferred heterogeneity distribution (based on AIC) with 18 support points. We use Kendall's $\tau$ to compute rank correlation. It is based on all possible pairs of individuals $(i, j)$ that can be formed from the discrete distribution. A pair $\left\{\left(v_{k i}, v_{l i}\right),\left(v_{k j}, v_{l j}\right)\right\}$ said to be concordant with respect to variables $(k, l)$ if $\left(v_{k i}-v_{k j}\right)\left(v_{l i}-v_{l j}\right)>0$ and discordant if $\left(v_{k i}-v_{k j}\right)\left(v_{l i}-v_{l j}\right)<0$. Let $c_{k l}$ be the number of concordant pairs and let $d_{k l}$ be the number of discordant pairs. We then compute Kendall's $\tau$ as $\tau_{k l}=(c-d)(c+d)^{-1}$. Note that we disregard the fraction $\sum_{s=1}^{Q} q_{s}^{2}$ of identical pairs drawn from the same location vector.

\section{The rewards for employment and entrepreneurship}

Previous evidence has indicated that unemployed men and women who enter selfemployment experience a larger earnings drop than the unemployed who return to wage work; see e.g., Evans and Leighton (1989; 1990) and Rissman (2003). To investigate the quality of employment and entrepreneurship transitions in our data, we examine economic outcomes for employees and entrepreneurs in the first calendar year after the transition out of unemployment. The results are presented in Table 4. They indicate that transitions to entrepreneurship on average are more successful than transitions to employment. This is partly because many of the new businesses survive (and apparently thrive) the first year, and partly because the entrepreneurship attempts become a stepping-stone for subsequent regular employment. One year after exit from unemployment, almost 90 percent of those who made a transition to entrepreneurship are still economically active - in the sense that they are either in entrepreneurship or in 
employment. In comparison, only 75 percent of those who made a direct transition to employment are still active. Entrepreneurs are also more successful in terms of income; both the mean and the median incomes are higher in the group of entrepreneurs than in the group of employees. This difference cannot be given a pure causal interpretation however, as the entrepreneurs in our data tend to have characteristics that imply higher earnings in both states. When we run a regression with log earnings as the dependent variable, we find that entrepreneurship premium is reduced from 0.34 log-points without other control variables to 0.20 log-points when we control for observed differences in age, education, nationality, and family situation (not shown in tables).

\begin{tabular}{|c|c|c|}
\hline & $\frac{\text { Transitions to employ- }}{\text { ment }}$ & Transitions to entrepreneurship \\
\hline \multicolumn{3}{|c|}{$\begin{array}{l}\text { Main economic activity one year after } \\
\text { (\%) }\end{array}$} \\
\hline Employment & 73.6 & 24.5 \\
\hline Entrepreneurship & 1.0 & 64.0 \\
\hline Other & 25.4 & 11.5 \\
\hline \multicolumn{3}{|c|}{$\begin{array}{l}\text { Total income first whole year after tran- } \\
\text { sition }\end{array}$} \\
\hline Mean & 251311 & 342474 \\
\hline P10 & 69762 & 120053 \\
\hline P25 & 161512 & 213307 \\
\hline P50 (median) & 252765 & 309644 \\
\hline P75 & 327603 & 429708 \\
\hline P90 & 409033 & 584304 \\
\hline Number of observations & 102,423 & 3,402 \\
\hline
\end{tabular}

Note: Total income comprises all personal income sources, including earnings, business income, and capital income.

\section{Concluding remarks}

Unemployment is the driving force behind many entrepreneurship endeavors. Yet, labor market policies targeted at unemployed workers typically focus on search for existing vacancies. There is not much emphasis on the creation of new jobs. For example, only around $4 \%$ of active labor market program slots are particularly targeted at encouraging/supporting entrepreneurship attempts. We have shown in this paper that the 
transition from unemployment to entrepreneurship is highly sensitive with respect to financial incentives, even more so than the transition from unemployment to regular employment. There are huge spikes in the entrepreneurship hazards around the time of unemployment insurance exhaustion. Taken together, these observations suggest that there is room for more job creation among unemployed workers. Our results also indicate that entrepreneurship transitions are significantly less cyclical than regular job transitions, implying that the relative importance of entrepreneurship rises in bad times. Thus, in times of economic crisis, it may be of particular importance to design labor market institutions such that they foster entrepreneurship among the unemployed. This conclusion is corroborated by our finding that transitions to entrepreneurship are rather generously rewarded, and sometimes also become a springboard for the return to regular employment.

\section{References}

Abbring, J. H. and Van den Berg, G. J. (2003) The Non-Parametric Identification of Treatment Effects in Duration Models. Econometrica, Vol. 71, No. 5 (September), 1491-1517.

Baumgartner, H. J. and Caliendo, M. (2008) Turning Unemployment into SelfEmployment: Effectiveness of Two Start-Up Programmes. Oxford Bulletin of Economics and Statistics, Vol. 70, No. 3, 347-373.

Berglann, H., Moen, E. R., Røed, K. and Skogstrøm, J. F. (2011) Entrepreneurship: Origins and Returns. Labour Economics, Vol. 18, 180-193.

Blanchflower, D. G. and Meyer, B. (1994) A Longitudinal Analysis of the Young SelfEmployed in Australia and the United States. Small Business Economics, Vol. 
6, 1-19.

Brinch, C. (2007) Non-Parametric Identification of the Mixed Hazards Model with Time Varying Covariates. Econometric Theory, Vol. 23, 349-354.

Card, D., Chetty, R. and Weber, A. (2007) The Spike at Benefit Exhaustion: Leaving the Unemployment System or Starting a New Job? American Economic Review, Vol. 97, No. 2 (PAP), 113-118.

Carrasco, R. (1999) Transitions to and from Self-Employment in Spain: An Empirical Analysis. Oxford Bulletin of Economics and Statistics, Vol. 61, No. 3, 315-341.

Eberwein, C., Ham, J. C. and LaLonde, R. J. (1997). The Impact of Being Offered and Receiving Classroom Training on the Employment Histories of Disadvantaged Women: Evidence from Experimental Data. Review of Economic Studies, Vol. 64, 655-82.

Evans, D. S. and Leighton, L. S. (1989) Some Empirical Aspects of Entrepreneurship, American Economic Review, Vol. 79, No. 3, 519-535.

Evans, D. S. and Leighton, L. S. (1990) Small business formation by unemployed and employed workers, Small Business Economics, Vol. 2, No. 4, 319-330.

Gaure, S. and Røed, K. (2007) How Tight is the Labour Market? Sources of Changes in the Aggregate Exit Rate from Unemployment across the Business Cycle. Journal of Business Cycle Measurement and Analysis, Vol. 3, No. 2, 155 - 174.

Gaure, S., Røed, K. and Zhang, T. (2007). Time and Causality: A Monte Carlo Assessment of the Timing-of-Events Approach. Journal of Econometrics, 141, 1159-1195.

Gaure, S., Røed, K., and Westlie, L. (2012) Job Search Incentives and Job Match Quality. Labour Economics, Vol. 19, 438-450. 
Goffe, W. L., Ferrier G. D., and Rogers, J. (1994) Global Optimization of Statistical Functions with Simulated Annealing. Journal of Econometrics, Vol. 60, 65-99.

Heckman, J. and Singer, B. (1984) A Method for Minimizing the Impact of Distributional Assumptions in Econometric Models for Duration Data. Econometrica, Vol. 52, 271-320.

Hodrick, R. and Prescott, E. C. (1997) Postwar U.S. Business Cycles: An Empirical Investigation. Journal of Money, Credit, and Banking, Vol. 29, No. 1, 1-16.

Kelley, D. J., Brush, C. G., Greene, P. G. and Litovsky, Y. (2011) Global Entrepreneurship Monitor - $\quad 2010 \quad$ Women’s Report (http://www.gemconsortium.org/docs/ download/768)

Kuhn, P. J. and Schuetze, H. J. (2001) Self-Employment Dynamics and SelfEmployment Trends: A study of Canadian Men and Women, 1982-1998. Canadian Journal of Economics, Vol. 34, 760-784.

Lindsay, Bruce G. (1983) The Geometry of Mixture Likelihoods: A General Theory. The Annals of Statistics, Vol. 11, 86-94.

McCall, B. P. (1994) Identifying State Dependence in Duration Models. American Statistical Association 1994, Proceedings of the Business and Economics Section, $14-17$.

Meager, N. (1992) Does Unemployment Lead to Self-Employment? Small Business Economics, Vol. 4, 87-103.

Parker, S. C. (2004) The Economics of Self-Employment and Entrepreneurship. Cambridge University Press.

Portugal, P. and Addison, J. T. (2008) Six Ways to Leave Unemployment. Scottish Journal of Political Economy. Vol. 55, No. 4, 393-419. 
Rissman, E. R. (2003) Self-Employment as an Alternative to Unemployment. Working Paper 2003-34, Federal Reserve Bank of Chicago.

Røed, K. and Skogstrøm, J. F. (2010) Creative Unemployment. IZA Discussion Paper No. 5373.

Røed, K. and Westlie, L. (2012) Unemployment Insurance in Welfare States: The Impacts of Soft Duration Constraints. Journal of the European Economic Association, Vol. 10, No. 3, 518-554.

Von Greiff, J. (2009) Displacement and Self-Employment Entry. Labour Economics, Vol 16, 556-565. 